\title{
DEVELOPMENT AND MANUFACTURE OF A PEANUT AIR-SCREEN CLEANER
}

\author{
ABD EL-TAWWAB, I. M.
}

Agric. Eng. Research Institute, AENRI, ARC, Dokki, Giza, Egypt.

(Manuscript received 2 September 2012)

\begin{abstract}
Cleanliness is an important quality characteristic for market acceptance of food products. The present work was carried out to develop a cleaning machine which can deal efficiently with the peanut seeds. A peanut cleaner was developed and constructed based on the application of some determined physical and aerodynamic properties of the peanut seeds (Giza-5). It consists of a set of oscillating sieve made of steels, mesh of different sizes. Upper screen (12.5 $\mathrm{mm}$ diameter) prevents pods bigger than shelled seeds, medium screen ( $8 \mathrm{~mm}$ diameter) retains medium peanut seeds and allows passage smaller peanut seeds, while bottom sieve retains smaller seeds. A centrifugal fan was incorporated to remove shills. The experimental research has aimed at quantitative and qualitative influence on separation quality indexes of the following operating parameters: kinematic factor, feed rate, air concentration coefficient, and air velocity ratio. Based on the data obtained by the measurements and qualitative indicators the cleaning process indexes have been determined, namely: cleaning efficiency, cleaning capacity and cleaning loss.

A prediction equation describing the cleaning process in the peanut cleaner using a mathematical model based on physical and aerodynamic properties of peanut and machine characteristics was carried. Results showed that the optimal kinematic factor and feed rate were 1.5 and $0.11 \mathrm{~kg} / \mathrm{m}^{2} \mathrm{~s}$, respectively to achieve cleaning efficiency of $97.5 \%, 2.45 \%$ cleaning loss and $410 \mathrm{~kg} / \mathrm{h}$ cleaning capacity. The cleaning efficiency of $97.3 \%$ with $3.8 \%$ cleaning loss was recorded at 0.3 air concentration coefficient and 1.3 air velocity ratio (air velocity $=7.54 \mathrm{~m} / \mathrm{s}$ ). The cleaning efficiency model showed a significant effect between the predicted and experimental result at $5 \%$ level of significance.
\end{abstract}

\section{INTRODUCTION}

The peanut, is known as the groundnut, has become an important food and export crop in several countries, such as China, USA, Nigeria, Niger, and Egypt. It is the fifth most important oilseed crop in the world after soybean, cotton seed, rape seed, and sunflower seed Nwokolo and Smartt (1996). In Egypt peanut grow very well in the desert areas which make it a good cash crop in the newly reclaimed areas. Shelled peanut seeds usually contain shells and pods which have to be removed for efficient and safe operation of processing equipment and production of good quality 
products. These impurities reduce the value of the crop and make it unfit for human consumption.

In an attempt to solve this problem, the present work was undertaken to develop and construct cleaning machine which can deal efficiently with the shelled peanut. The idea was to subject the mixture to a preliminary air blast to get rid of the shells without loss of seeds prior to using the sieve unit.

Abd El-Tawwab et al (2007) developed and fabricated a separating machine which can deal efficiency with secondary productions resulted from rice milling operation. Results indicated that the optimum separating efficiency was accomplished with sieve oscillation of $300 \mathrm{cycle} / \mathrm{min}$. To ensure a good separating efficiency of not less than 90 $\%$ the sieve slope should be limited to about 8 degree. The optimum separating efficiency resulted with kinematic factor ranged from 4 to $10 \mathrm{~m} / \mathrm{sec}^{2}$. The sieve stroke length required to achieve the highest separating efficiency was $15 \mathrm{~mm}$.

According to Mohsenin (1970) the proper air speed can be determined from aerodynamic properties of agricultural materials. These properties are terminal velocity and drag coefficient. If an object is dropped from a sufficient height, the force of gravity will accelerate it until the drag force exerted by the air, balances the gravitational force. It will then fall at a constant velocity called the terminal velocity.

Klenin et al (1985) defined the terminal velocity as the air velocity required for seed suspense or balance. They mentioned that when seeds are exposing to air current through a certain path begin to move then remain constant at a certain velocity, at this velocity the net gravitational acceleration force equals the resistance upward drag force. At this velocity the seed is remaining constant and in this case this velocity called terminal velocity.

Picket and West (1988) defined sieving as a process in which material mixture is moved over a perforated surface with openings of specified shape and size having one or more oscillating sieves and a fan delivering air through the sieves. Air is used to remove light materials from mixtures, assist to position particles over sieve opening and moves particles along sieve surface if they do not pass through openings.

Zhao et. al. (1999) reported that grain conveyance on the sieve is influenced by air velocity, which leads to initial segregation of grain from materials other than grain.

Hollatz and Quick (2003) reported that at low feed rates, aerodynamic separation of grain from straw and chaff took place over the sieve and at higher feed rate, material particles were no longer supported aerodynamically, which forms a mat on sieve, increasing grain losses.

Adewumi et. al. (2006) suggested studying the distribution and spread pattern of grain relative to the distance from the plane at which materials are discharged as an approach to investigating the separation of grain from materials other than grain in a 
horizontal air stream. This study was undertaken to investigate grain separation and cleaning efficiency distribution in the cleaning unit of a conventional stationary raspbar grain thresher.

The aim of this work was to:

1- Record preliminary information on the physical and aerodynamic properties of the Peanut in order to develop a suitable separation device able to separate seeds from shells with the minimum of loss.

2- Develop a mathematical model for describing the crop-machine interaction in the cleaning process.

\section{MATERIALS AND METHODS}

Cleaning operation is defined as the final operation for seeds separation from other blemishes (pods, empty pods, shells and sand). These different components are separated according to several separation theories. The separation of peanut seeds from other blemishes could be achieved using aerodynamic - mechanical separation.

\section{1- Physical properties:}

The Peanut variety (Giza-5) was brought from the Agricultural Research Station in Ismailia, Egypt. To carry out research on the separation process the pods of this variety were shelled. The components obtained from the shelled peanut pods by using a shaker apparatus are: intact seeds, split seeds, and shells with three sieving mesh $(12.5,8.0$, and $6.3 \mathrm{~mm})$. A sieving mesh of $12.5 \mathrm{~mm}$ was used to separate only big shells and unshelled pods from the shelled components, while meshes of 8.0 and 6.3 $\mathrm{mm}$ were used to separate the mixture of intact and split seeds, and small shells. Because this was an experimental process, it was performed manually. A sample of 100 particles for each peanut component was taken randomly to measure their dimensions (length - $L$, width - $W$, and thickness - $T$ ) with dial calipers and masses with a sensitive balance with an accuracy of $0.05 \mathrm{~mm}$ and $0.001 \mathrm{~g}$, respectively. The geometric diameter was calculated using the following equations Gharibzahedi et. al.(2010b): $d_{g}=\sqrt[3]{L . W . T}$

\section{2- Measurement of aerodynamic properties}

Terminal velocity was measured using an air column. For each test, a sample (shells, intact seeds, split seeds, and unshelled seeds) was dropped into the air stream from the top of the air column, and air was blown up the column to suspend the material in the air stream. The air velocity near the location of the sample suspension was measured by a digital anemometer having a least count of $0.1 \mathrm{~ms}^{-1}$ (Gharibzahedi et. al., 2010a,b). 


\section{3- Cleaning machine:}

A local cleaning machine was modified, developed, and tested at the workshop of Agric. Eng. Res. Inst. (AENRI) for separating shells and unshelled from peanut seeds. The proposed cleaning machine was developed and modified by introducing a horizontal air stream over the sieve unit. Where the shells were blown rearward without contacting the upper sieve and only seeds landed on the sieve unit. Also the seed was dispersed before it reached the upper sieve. Cleaning takes place on the basis of difference in aerodynamic and physical properties of peanut seeds. The modification occurred can be concluded as follows:

1- The fan was placed above the sieve unit and fixed on opposite direction to feeding device for removing the shells rearward during the peanut seeds falling from feeding device to sieve unit.

2- According to the peanut seeds dimension, the sieves were replaced by another three sieves with perforation dimensions of $12.5,8$, and $6.3 \mathrm{~mm}$.

The main components of the developed cleaning machine as sketched in Fig. 1 are as follows:

\section{The main frame:}

All separating machine parts were mounted to a simple main frame which constructed from steel squares of $50 \times 50 \mathrm{~mm}$. The frame dimensions are $75 \times 230 \times 148$ $\mathrm{cm}$ (width $\times$ length $\times$ height) as shown in Fig. (1)

\section{The hopper:}

The hopper was made of iron sheet of $1.5 \mathrm{~mm}$ thickness. It is mounted on the top of the frame. It has adjustable gate opening used for feeding material at the required feed rates. The hopper section in side view is trapezoidal in shape to give a suitable slope for the mixture to slide smoothly.

\section{Fan:}

The air flow was produced by means of a multiple-bladed fan. The fan is of the radial type with 5-blades and $40-\mathrm{cm}$ diameter. The fan was fixed on the frame between the feeding device and screen unit. The blades speed and two shutters are used to control the amount of air delivered by the fan. An air blast was blown out horizontally to meet the falling mixture. Where by lighter materials such as shells and dust can be separated entirely by aerodynamic action.

\section{Sieving unit:}

The sieving unit consists of three removable oscillating sieves moving at the same direction. The upper, middle and bottom sieves are perforated sheets with circular mesh with 12.5, 8 and $6.3 \mathrm{~mm}$ diameter respectively. Sieve box was tilted at about 5 degrees to the horizontal. It is mounted freely to the frame by four adjustable 
hangers, which provide the necessary flexibility required for the oscillation and to obtain suitable slope of the sieving unit. It gets its oscillation action by a lever fixed on an eccentric which takes its motion by means of pulleys and belts. Separation with three sieves was achieved by difference in size. Upper sieve (12.5 mm diameter) prevent pods bigger than shelled seeds while middle sieve $(8 \mathrm{~mm}$ diameter) retains medium shelled seeds and allows passage small shelled seeds. The bottom sieve retains small shelled seeds and allows passage fine and dust material.

\section{4- Power source:}

An electric variable speed motor of $2.21 \mathrm{~kW}$ ( $3 \mathrm{hp}$ ) was installed to the frame of the separating unit. The power is transmitted to the moving parts of the machine by means of pulleys and belts.

\section{Principle of operation of peanut cleaner:}

Peanut head samples, which have already been weighed, were fed manually into the hopper and they flowed under gravity on the reciprocating upper sieve. The feed rate was controlled by the height of the hopper gate. As seeds and shells passed across air stream, the shells are blown off, while seeds fall on the upper sieve. As the sieves reciprocate due to horizontal displacement, allowing shelled seeds to pass through the upper sieve openings to the lower sieves and moving seeds to the front of the cleaner to be discharged.

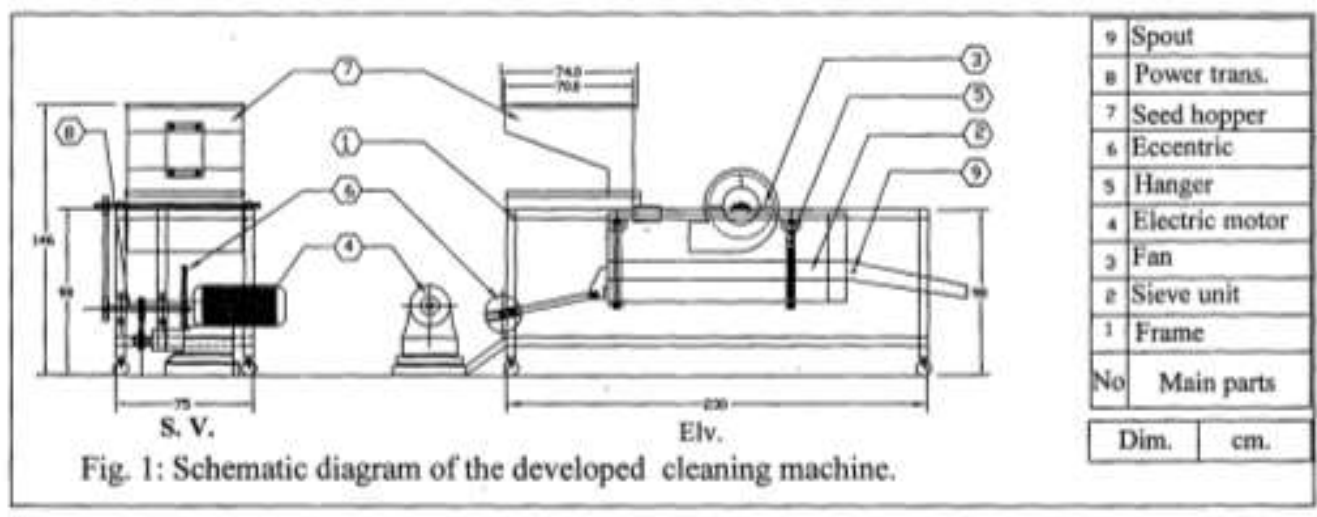

The following engineering factors were studied to observe their effect on the cleaning machine performance:

\section{1- Kinematic factor (K):}

In constructing this machine, it is important to find the best solution on how to move the product on the sieve unit, and this requires knowledge of the relationship between the motion characteristics of the product and other factors such as the number of oscillations per minute and amplitude of sieve vibrations Kanafojski and Karwowski, (1976). Fig. 2 shows the forces that affect the seed during separation on 
the sieve surface. The particle on the sieve plane will take the same acceleration of the sieve. Thus the particle will start sliding over the sieve downwards when:

$$
\begin{aligned}
& \frac{\omega_{1}^{2} r}{g}=\mathrm{K}_{1}=\frac{\sin (\varphi-\beta)}{\cos \varphi} \\
& \text { Hence, } K_{1}=\frac{\sin (25-4)}{\cos 25}=0.35
\end{aligned}
$$

Therefore, $\mathrm{V}_{1}=0.16 \mathrm{~m} / \mathrm{s}, \omega_{1}=21.39 \mathrm{~s}^{-1}$, and $\mathrm{N}_{1}=204 \mathrm{rpm}$.

And the particle will start sliding over the plane upward when:

$$
\begin{aligned}
& \frac{\omega_{2}^{2} r}{g}=K_{2}=\frac{\sin (\varphi+\beta)}{\cos \varphi} \\
& \text { Hence, } K_{2}=\frac{\sin (25+4)}{\cos 25}=0.53
\end{aligned}
$$

Therefore, $\mathrm{V}_{2}=0.197 \mathrm{~m} / \mathrm{s}, \omega_{2}=26.32 \mathrm{~s}^{-1}$, and $\mathrm{N}_{2}=251.3 \mathrm{rpm}$.

In conclusion, the following cases may be distinguished:

if $K_{1} \geq K$, the basic mass remains stationary on the sieve,

if $K_{1}<K<K_{2}$, the basic mass shifts downward only,

if $\mathrm{K}_{1}<\mathrm{K}>\mathrm{K}_{2}$ the basic mass shifts upward and downward (but more upward),

According to Kanafojski and Karwowski, (1976) the maximum velocity of the seed (v) at which the seed can still pass through the sieve perforations and can't jump over the sieve will be expressed as follows:

$$
V_{\max }=(D-L / 2 \cos \beta) / \sqrt{[2(D-L / 2) \sin \beta+d / 2 \cos \beta] / g}
$$

$V_{\max }=(0.0125$

$0.00972 / 2 \cos 4) /$

$\sqrt{[2(0.0125-0.00972 / 2) \sin 4+0.00853 / 2 \cos 4] / 9.81}$

$V_{\max }=0.325 \mathrm{~m} / \mathrm{s}$

Hence, $\omega_{\max }=43.3 \mathrm{~s}^{-1}$ and $N_{\max }=414 \mathrm{rpm}$.

Therefore, theoretical kinematic factor $\left(\mathrm{K}_{\max }\right)=1.43$

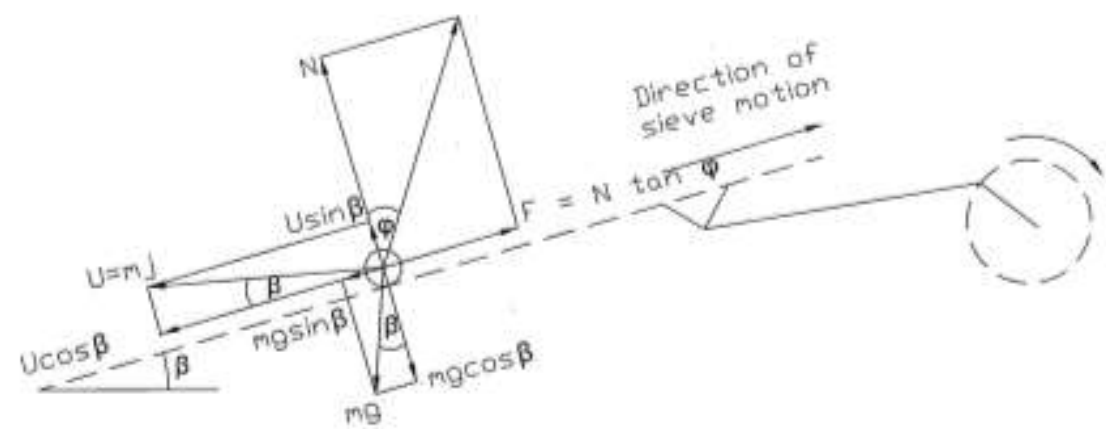

Fig. 2. Motion characteristics of a seed on the sieve surface. 
where:

$\mathrm{U}=\mathrm{mr} \omega^{2} \cos \omega \mathrm{t}, \mathrm{N}$,

$\mathrm{t}=$ rotating time of the crankshaft, $\mathrm{s}$,

$r=$ radius of the crank shaft $=7.5 \mathrm{~mm}$,

$\varphi=$ friction angle $=25$ degree,

$\beta=$ inclination angle of the sieve $=4$ degree,

$\mathrm{N}_{1} \quad$ = revolution speed of crank when particle start sliding downward, rpm,

$\mathrm{N}_{2}$ = revolution speed of crank when particle start sliding upward, rpm,

$\omega_{1}=$ angular speed of crank when particle start sliding downward, $\sec ^{-1}$,

$\omega_{2}=$ angular speed of crank when particle start sliding upward, $\sec ^{-1}$,

$\mathrm{V}_{1}=$ linear speed of crank when particle start sliding downward, $\mathrm{m} / \mathrm{sec}$,

$\mathrm{V}_{2}=$ linear speed of crank when particle start sliding upward, $\mathrm{m} / \mathrm{sec}$,

$\mathrm{K}_{1}=$ kinematic factor when particle start sliding downward,

$\mathrm{K}_{2}=$ kinematic factor when particle start sliding upward,

$\mathrm{m}=$ the seed mass $=2.13 \mathrm{~g}$,

$\mathrm{g}=$ acceleration due to gravity $=9.81 \mathrm{~m} / \mathrm{s}^{2}$,

$\mathrm{D}=$ diameter of sieve perforation $=12.5 \mathrm{~mm}$,

$L, d=$ seed dimensions $=9.72,8.53 \mathrm{~mm}$.

Depending on the magnitude of the acceleration $r \omega^{2}$ the seed may either slide only down the sieve or up and down or finally it may be thrown away from the surface of the sieve.

The developed cleaning machine was tested and evaluated under the effect of the kinematic factor of. $0.5,1.0,1.5,2.0$ and 2.5.

\section{2- Feed rate:}

Sifting of seeds through the sieve openings depends on the loading of the sieve and to be exact on the thickness of the material layer. Five different feed rates of $0.09,0.10,0.11,0.12$ and $0.13 \mathrm{~kg} / \mathrm{m}^{2} \mathrm{~s}$ were studied.

$$
\mathrm{F}=\mathrm{Q}_{\mathrm{m}} / \mathrm{S}_{\mathrm{m}},\left(\mathrm{kg} / \mathrm{m}^{2} \mathrm{~s}\right)
$$

Where:

$\mathrm{F}=$ feed rate, $\mathrm{kg} / \mathrm{m}^{2} \mathrm{~s}$,

$\mathrm{Q}_{\mathrm{m}}=$ amount of mixture, $\mathrm{kg} / \mathrm{s}$, and

$\mathrm{S}_{\mathrm{m}}=$ area of sieve, $\mathrm{m}^{2}$.

\section{5- Air concentration coefficient:}

The separation of the seed mix in an air stream depends not only the ratio between the air velocity and terminal velocity of the particles but on the quantity of particles entrained per unit volume of the air flow. The concentration of air is characterized by a coefficient $\lambda$ which expressed as Klenin and Popov (1985): 


$$
\lambda=\frac{q_{s}}{Q_{a}}
$$

Where:

$\mathrm{q}_{\mathrm{s}}=$ amount of impurities (shells), $\mathrm{kg} / \mathrm{s}$,

$\mathrm{Q}_{\mathrm{a}}=$ air flow rate through the duct, $\mathrm{kg} / \mathrm{s}$.

The quantity of air passing through the duct per unit time is equal to:

$$
\begin{aligned}
& \mathrm{Q}_{\mathrm{a}}=\rho_{\mathrm{a}} \mathrm{AV}_{\mathrm{a}} \mathrm{kg} \mathrm{s}^{-1} \\
& \lambda=\frac{q_{s}}{\rho_{a} A V_{a}}
\end{aligned}
$$

Where:

$\rho_{\mathrm{a}}=$ density of air $=1.2 \mathrm{~kg} / \mathrm{m}^{3}$,

$A=$ area of cross section of the duct $=0.18 \mathrm{~m}^{2}$, and

$\mathrm{V}_{\mathrm{a}}=$ air velocity, $\mathrm{m} / \mathrm{s}$.

The experiments were carried out by using different levels of air concentration coefficients as, $0.15,0.20,0.25,0.30,0.35$ and 0.40 .

\section{6- Air velocity ratio:}

The velocity of the air at the exit of the fan should be more than the terminal velocity of impurities which have to be removed, which expressed as Klenin and Popov (1985):

$$
\alpha=\frac{V_{a}}{V_{t}}
$$

Where:

$a=$ ratio between air velocity and shells terminal velocity,

$V_{\mathrm{a}}=$ air velocity, $\mathrm{m} / \mathrm{s}$, and

$V_{\mathrm{t}}=$ maximum shells terminal velocity $=5.8 \mathrm{~m} / \mathrm{s}$.

The effect of the ratio between the air velocity and the terminal velocity of the shells on the cleaning machine performance was studied. The experiments were achieved by using different values of velocity ratios as, 1.0, 1.1, 1.2, 1.3, and 1.4.

The following measurements were carried out to investigate the effect of the above-mentioned parameters on the experimental machine's performance.

\section{1- Cleaning efficiency:}

$$
C_{e}=\frac{s_{o}}{s_{o}+s_{h}} \times 100
$$

Where

$\mathrm{C}_{\mathrm{e}}=$ cleaning efficiency, \%,

$\mathrm{S}_{\mathrm{o}}=$ mass of pure seed at the outlet, $\mathrm{kg}$, and

$S_{h}=$ mass of shells in cleaned seed, $\mathrm{kg}$. 
A mathematical model, using dimensional analysis, was used to characterize the cleaning process of peanut in a cleaner machine. Dimensional analysis is based on the Buckingham $\mathrm{Pi}$ theorem cited by Murphy, (1950). The variables and their corresponding dimensions used in model development are given in Table1.

Table 1. The variable affecting the efficiency of separation.

\begin{tabular}{|c|l|c|c|}
\hline & \multicolumn{1}{|c|}{ Variable } & Symbol & Dimension \\
\hline 1 & Cleaning efficiency, \% & $\mathrm{C}_{\mathrm{e}}$ & -- \\
\hline 2 & Angular velocity $=25.5,36.1,44.29$, an $51.1 \mathrm{~s}^{-1}$ & $\omega$ & $\mathrm{T}^{-1}$ \\
\hline 3 & Crank radius $=7.5 \mathrm{~mm}$ & $\mathrm{r}$ & $\mathrm{L}$ \\
\hline 4 & Gravitational acceleration $=9.81 \mathrm{~m} / \mathrm{s}^{2}$ & $\mathrm{~g}$ & $\mathrm{LT}^{-2}$ \\
\hline 5 & Feed rate $=0.09,0.1,0.11,0.12$, and $0.13 \mathrm{~kg} / \mathrm{m}^{2} \mathrm{~s}$ & $\mathrm{~F}$ & $\mathrm{M} \mathrm{L}^{-2} \mathrm{~T}^{-1}$ \\
\hline 6 & Seeds density $=930 \mathrm{~kg} / \mathrm{m}$ & $\rho$ & $\mathrm{ML} \mathrm{L}^{-3}$ \\
\hline 7 & Air velocity ratio $=1.0,1.1,1.2,1.3$, and 1.4 & $\mathrm{a}$ & --- \\
\hline 8 & Air concentration coefficient $=0.15,0.20,0.25,0.30$, and 0.40 & $\lambda$ & ---- \\
\hline
\end{tabular}

The mathematical expression for cleaning efficiency $\left(C_{e}\right)$ between the dependent and independent variables is:

$$
C_{e}=f(\omega, r, g, F, \rho, a, \lambda)
$$

The statistical model suggested is as follows:

$$
\begin{aligned}
& C_{e}=f\left(\frac{\omega^{2} r}{g}, \frac{F}{\rho \sqrt{g r}}, \alpha, \lambda\right) \\
& \Pi_{1}=\mathrm{f}\left(\Pi_{2}, \Pi_{3}, \Pi_{4}, \Pi_{5}\right)
\end{aligned}
$$

\section{2- Cleaning Loss:}

$$
C_{L}=\frac{s_{L}}{s_{i}} \times 100
$$

Where

$$
\begin{aligned}
& C_{L}=\text { cleaning loss, } \%, \\
& S_{L}=\text { mass of seed at the shells outlet, } g \text {, and } \\
& S_{i}=\text { mass of seeds at input, } g .
\end{aligned}
$$




\section{3- Cleaning capacity:}

The cleaning capacity was calculated according to the following equation Amin, (1994):

$$
C_{c}=\frac{S_{o} \times 60}{T_{c}}
$$

Where:

$\mathrm{C}_{\mathrm{c}}=$ cleaning capacity of the machine, $\mathrm{kg} / \mathrm{h}$,

$\mathrm{S}_{\mathrm{o}}=$ mass of pure seed at the outlet, $\mathrm{kg}$, and

$\mathrm{T}_{\mathrm{c}}=$ cleaning time, $\min$.

\section{RESULTS AND DISCUSSION}

\section{1- Physical properties:}

Some physical properties of peanut (Giza-5) such as the length, width, thickness and mass were measured. The mean values of the dimensions as well as their geometric diameter and standard deviation are presented in Table 2. To obtain a seed classification, the dimensions and masses of seeds were investigated after using three sieve dimensions (12.5, 8.0 and $6.3 \mathrm{~mm})$. The large dimensions and masses of intact seeds were obtained on a sieve surface of $8.0 \mathrm{~mm}$, and small dimensions of intact seeds on a sieve surface of $6.3 \mathrm{~mm}$. The geometric diameter and mass values of the intact seeds were found to be up to $11.73 \mathrm{~mm}$ and $0.89 \mathrm{~g}$ on a sieve surface of 8.0 $\mathrm{mm}$, while these values were $8.83 \mathrm{~mm}$ and $0.40 \mathrm{~g}$ on a sieve surface of $6.3 \mathrm{~mm}$. 
Table 2. Dimensions and masses of pods, intact and split seeds on three sieve sizes.

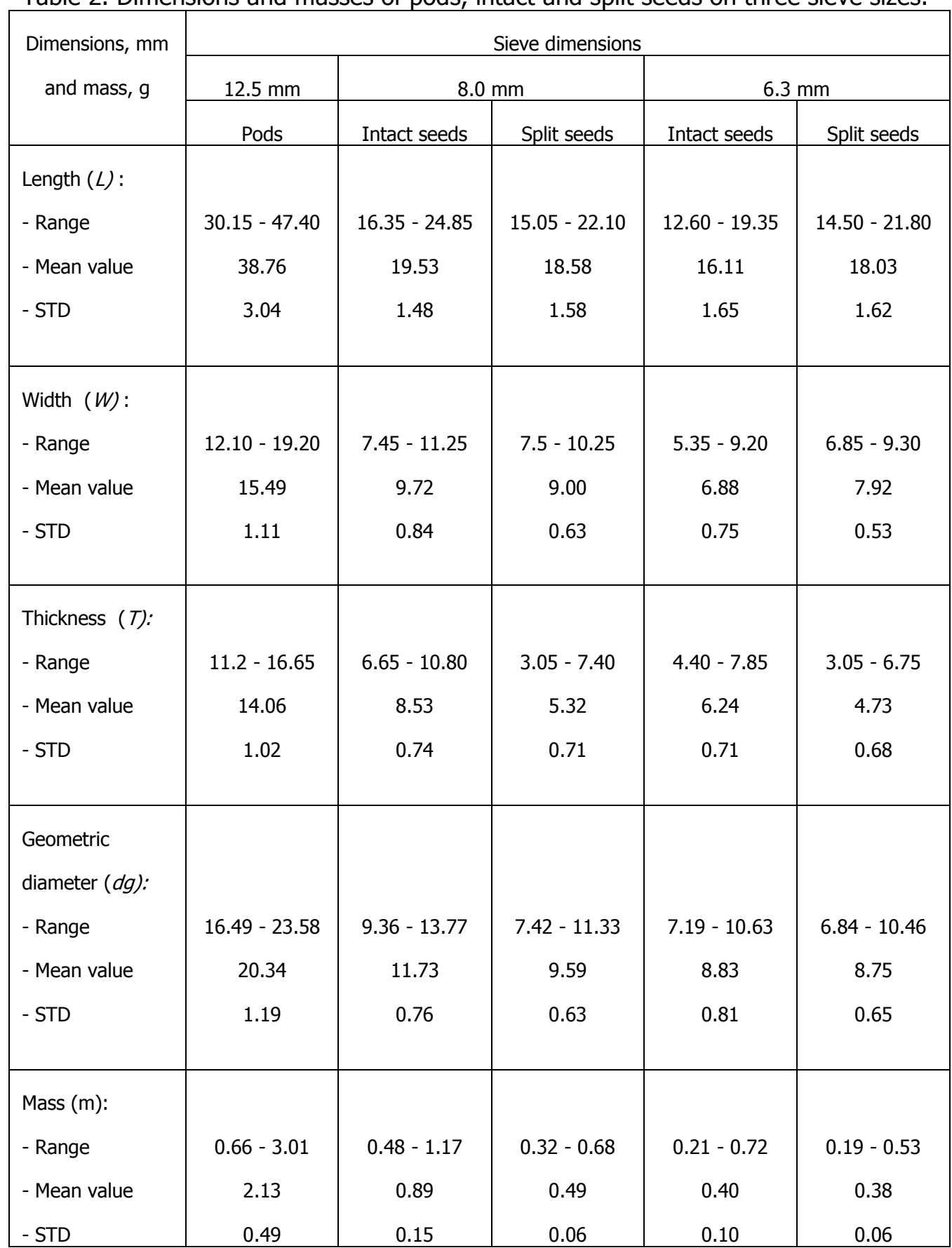

\section{2- Aerodynamic properties:}

The terminal velocity is the air velocity required to suspend or balance a particle. The terminal velocities of peanuts and shelled components in a vertical air stream were measured, and the velocity curves of them are shown in Fig. 2. The terminal velocity for pods ranged between 7.7 to $14.8 \mathrm{~m} \mathrm{~s}^{-1}$. Intact seeds are the main components obtainable at the end of a separation process. Where, the terminal velocity varied between7.2 to 12.8 and 6.5 to $10.7 \mathrm{~m} \mathrm{~s}^{-1}$ for intact seeds and split 
seeds respectively Hence, to remove lighter material from the peanut seeds by an air stream, the velocity of airflow may not exceed $6.5 \mathrm{~m} \mathrm{~s}^{-1}$. Also, Fig. 3 shows that terminal velocities of shells ranged between 2.2 to $5.8 \mathrm{~m} \mathrm{~s}^{-1}$. Generally, results show that there is a great difference between the terminal velocities of peanut seeds and shells. This property makes peanut material somewhat easy to separate aerodynamically. Hence, airflow velocity value of $6.5 \mathrm{~m} \mathrm{~s}^{-1}$ is sufficient to remove all shells from the peanut seeds without loss.

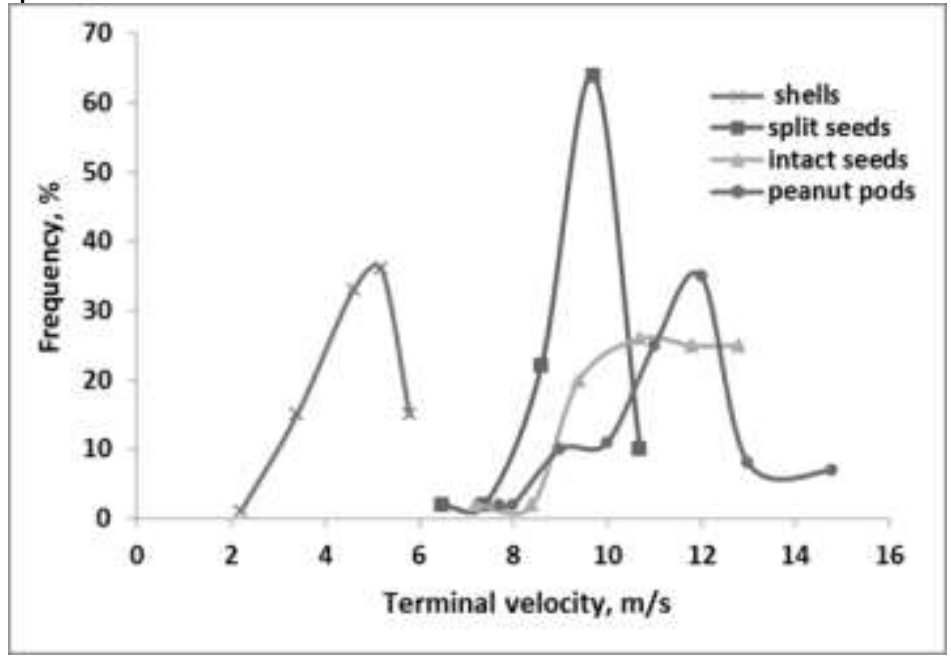

Fig. 3. Terminal velocity curves of peanut pods, intact seeds, split seeds and shells (Giza-5).

\section{3- Kinematic factor (K):}

Figure 3 shows the effect of kinematic factor $(K)$ on the cleaning efficiency. As seen in the figure there was an initial increase in the cleaning efficiency with increasing kinematic factor. Where, with increasing kinematic factor $\left(\omega^{2} r / g\right)$ to some limiting value, the passage of seeds through the sieve holes increased and cleaning efficiency improved. The maximum cleaning efficiency of $97.5 \%$ was obtained at kinematic factor of 1.5. Thereafter, the cleaning efficiency decreased with increasing kinematic factor. Where, particle velocity on the sieve surface must not be too high, or the peanut seeds will pass by the sieve openings instead of falling through. While the increasing of cleaning efficiency could be due to the material having more resident time on the oscillating sieve.

Also Fig. 4 shows the cleaning capacity increased with the kinematic factor up to 1.5. Where, the cleaning capacity increased from 290 to $410 \mathrm{~kg} / \mathrm{h}$ when the kinematic factor increased from 0.5 to 1.5 . Thereafter, the cleaning capacity remained unchanged when kinematic factor increased from 1.5 to 2.5 .

Also Fig. 4 shows the cleaning loss of about $2.5 \%$ and remained unchanged when the kinematic factor increased up to 1.5 . Thereafter, the cleaning loss 
significantly increased with kinematic factor. Where, the cleaning loss was 2.45, 9.5 and 12.4 when the kinematic factor was $1.5,2.0$, and 2.5 respectively.

Generally, experimental results show that the optimal kinematic $\left(\omega^{2} \mathrm{r} / \mathrm{g}\right)$ was 1.5 to achieve the desired performance of cleaner machine, that is, cleaning efficiency = $97.5 \%$, cleaning loss $=2.45 \%$ and cleaning capacity $=410 \mathrm{~kg} / \mathrm{h}$. Therefore, angular velocity, $\omega=44.29 \mathrm{~s}^{-1}$, revolution velocity, $\mathrm{N}=422.9 \mathrm{rpm}$, and linear velocity, $\mathrm{V}=$ $0.33 \mathrm{~m} / \mathrm{s}$. Therefore, it is clear that the experimental results meet closely with the theoretical data.

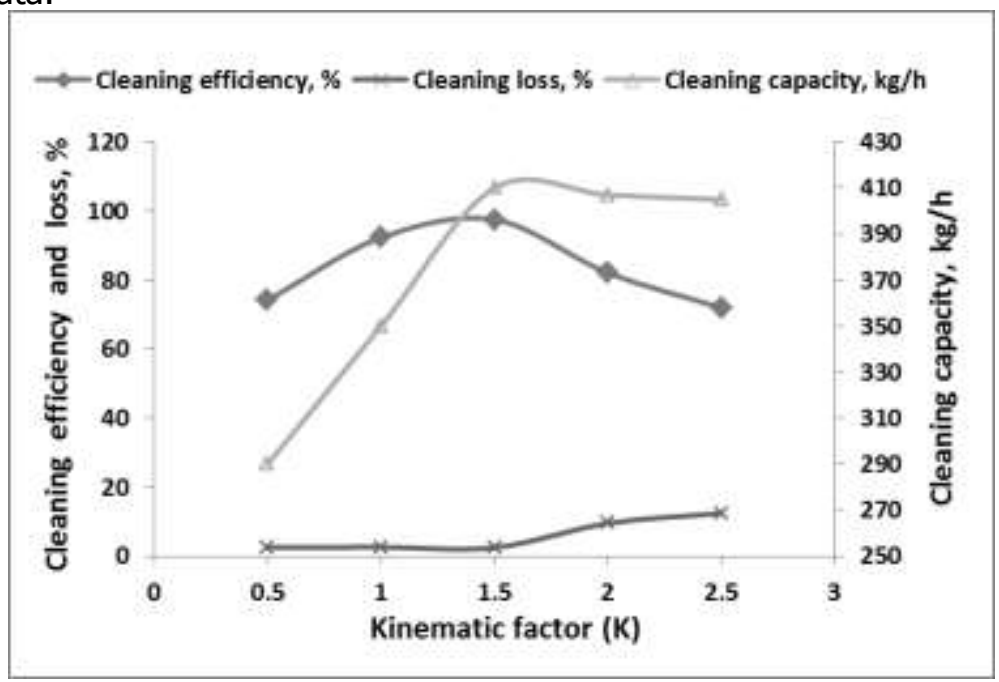

Fig. 4: Effect of kinematic factor (K) on cleaning efficiency, cleaning loss and cleaning capacity.

\section{4- Feed rate:}

It can be seen from Fig. 5 there was an initial increase in the cleaning efficiency with increasing feed rate. Where the maximum cleaning efficiency of $97.8 \%$ was achieved at $0.11 \mathrm{~kg} / \mathrm{m}^{2} \mathrm{~s}$. But with further increased of feed rate from 0.11 to 0.13 $\mathrm{kg} / \mathrm{m}^{2} \mathrm{~s}$ (load on the sieve increased), the cleaning efficiency significantly decreased from $97.8 \mathrm{~kg} / \mathrm{h}$ to $72.5 \mathrm{~kg} / \mathrm{h}$. The behaviors of the cleaning efficiency against the feed rate may be due to increasing load intensity on the sieve.

The cleaning capacity is governed by the optimal load on the sieve. Figure 5 shows the cleaning capacity was directly proportional to the feed rate, until some limiting load after which it decreased. Where, the cleaning capacity significantly increased from $290 \mathrm{~kg} / \mathrm{h}$ to $420 \mathrm{~kg} / \mathrm{h}$ when the feed rate ranged from 0.09 to 0.12 $\mathrm{kg} / \mathrm{m}^{2} \mathrm{~s}$. Thereafter, cleaning capacity highly decreased to $380 \mathrm{~kg} / \mathrm{h}$ when feed rate increased to $0.13 \mathrm{~kg} / \mathrm{m}^{2} \mathrm{~s}$. Therefore, the maximum cleaning efficiency of $97.8 \%$ and maximum cleaning capacity of $420 \mathrm{~kg} / \mathrm{h}$ was achieved at feed rate of 0.11 and 0.12 
$\mathrm{kg} / \mathrm{m}^{2} \mathrm{~s}$ respectively. Therefore, significant decreased of cleaning efficiency occurred earlier than the maximum cleaning capacity. Thus, the maximum cleaning capacity was greater than that which occurred at the highest efficiency.

The data of cleaning loss percentage reveal that, the feed rate ranged from 0.09 to $0.11 \mathrm{~kg} / \mathrm{m}^{2} \mathrm{~s}$ did not have a significant effect on seed loss. While, by increasing feed rate from 0.11 to $0.13 \mathrm{~kg} / \mathrm{m}^{2} \mathrm{~s}$ the cleaning loss was dramatically increased from 3.1 $\%$ to $12.7 \%$.

Generally, the feed rate was selected as $0.11 \mathrm{~kg} / \mathrm{m}^{2} \mathrm{~s}$ that it corresponded to the desired requirement, that is, cleaning efficiency $=97.8 \%$, cleaning losses $=3.1 \%$ and cleaning capacity $=410 \mathrm{~kg} / \mathrm{h}$.

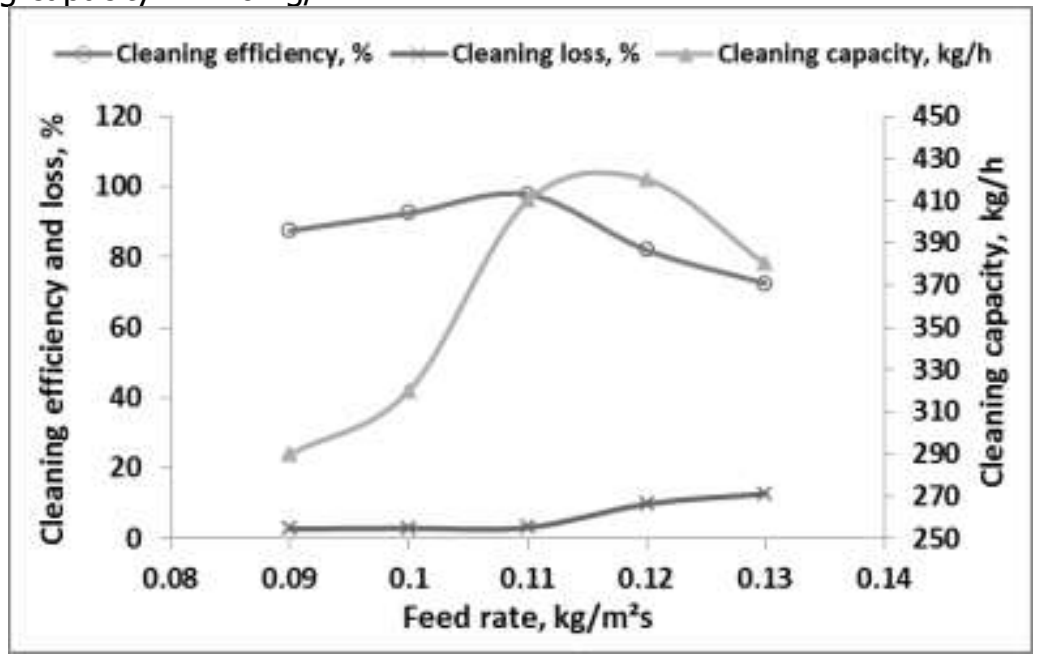

Fig. 5: Effect of feed rate on cleaning efficiency, cleaning loss and cleaning capacity.

\section{5- Air concentration coefficient:}

The behavior of the cleaning efficiency with increasing air concentration coefficient is presented in Fig. 6 . The cleaning efficiency remained unchanged when air concentration increased from 0.15 to 0.3 . Thereafter, behavior shows that increasing the air concentration coefficient above 0.3 leads to a subsequent decreasing in the cleaning efficiency. Where, the cleaning efficiency of $97.2 \%$ was achieved at 0.3 air concentration coefficient. On other hand, the minimum cleaning efficiency of $70 \%$ was recorded at 0.4 air concentration coefficient.

Also Fig. 6 shows the cleaning capacity was inversely related to air concentration coefficient. Where the maximum cleaning capacity of $415 \mathrm{~kg} / \mathrm{h}$ was achieved at 0.15 air concentration coefficient. On other hand cleaning capacity decreased to $380 \mathrm{~kg} / \mathrm{h}$ when air concentration increased to 0.4 .

It is noticed from Figure 5 the air concentration coefficient ranged from 0.15 to 
0.3 did not have a significant effect on cleaning loss. But, when the air concentration coefficient increased from 0.3 to 0.4 , cleaning loss increased from $3.8 \%$ to $15.2 \%$.

Generally, the optimal performance of the experimental cleaner machine was recorded at 0.3 air concentration to achieve $97.2 \%$ cleaning efficiency, $3.8 \%$ cleaning loss, and $400 \mathrm{~kg} / \mathrm{h}$ cleaning capacity.

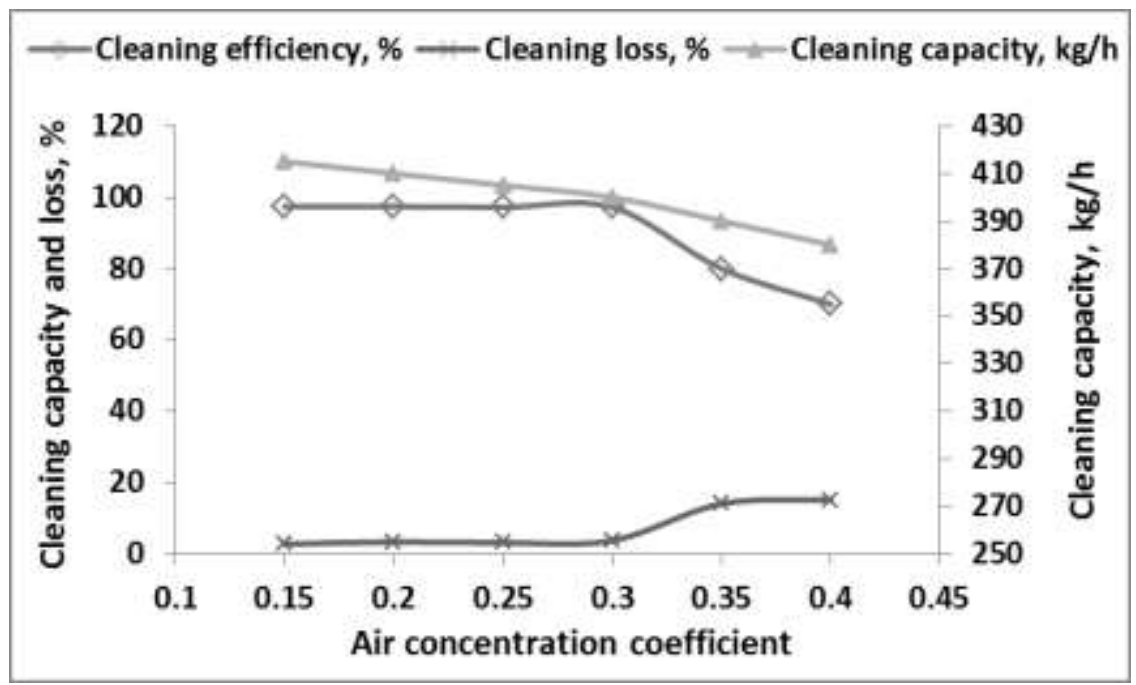

Fig. 6: Effect of air concentration coefficient on cleaning efficiency, cleaning loss and cleaning capacity.

\section{6- Air velocity ratio:}

The results of Fig. 7 show that the cleaning efficiency was directly proportional with the air velocity ratio. Where, the minimum separation efficiency of $74.2 \%$ was recorded at 1.0 air velocity ratio. On other hand, the maximum cleaning efficiency as $97.7 \%$ was achieved when air velocity ratio of 1.4 . Therefore, the maximum air velocity equal $8.12 \mathrm{~m} / \mathrm{s}$ to separate all shells from shelled peanut seeds. The behavior of the relationship may be due to initial insufficient air for cleaning and as the air velocity increased the seed cleaning efficiency increased. Where, by increasing air velocity the mat of peanut material coming from the feeding device was dispersed before it reached the upper sieve. Also, it is observed that the shells was blown out of the cleaner without contacting the upper sieve and only seed landed on this sieve. While the lowest value of separation efficiency at lower air velocity ratio was due to the presence of some shells with the seeds recovered.

Also, Fig. 7 shows the air velocity ratio did not have a major effect on the cleaning capacity. 
Fig. 7 presents the effect of air velocity ratio on cleaning loss. The graph shows an initial decrease in cleaning loss with increasing air speed. Then, the air is insufficient to separate impurity, but an increase in air velocity cause cleaning loss to increase. This may be due to excessive air velocity fluidizes the seed, carrying it to the back of the sieve and depositing it along with the shells. Where, the minimum cleaning loss of $2.1 \%$ with $94.8 \%$ cleaning efficiency and $415 \mathrm{~kg} / \mathrm{h}$ cleaning capacity were achieved at 1.2 air velocity ratio $(6.96 \mathrm{~m} / \mathrm{s}$ air velocity). While, the maximum cleaning loss of $12.3 \%$ with maximum cleaning efficiency of $97.7 \%$ and $412 \mathrm{~kg} / \mathrm{h}$ cleaning capacity were recorded at air velocity ratio of $1.4(8.12 \mathrm{~m} / \mathrm{s}$ air velocity).

Generally the optimal air velocity ratio of $1.3(7.54 \mathrm{~m} / \mathrm{s})$ was recorded to achieve $97.3 \%$ cleaning efficiency, $410.5 \mathrm{~kg} / \mathrm{h}$, as well as $4.5 \%$ cleaning loss.

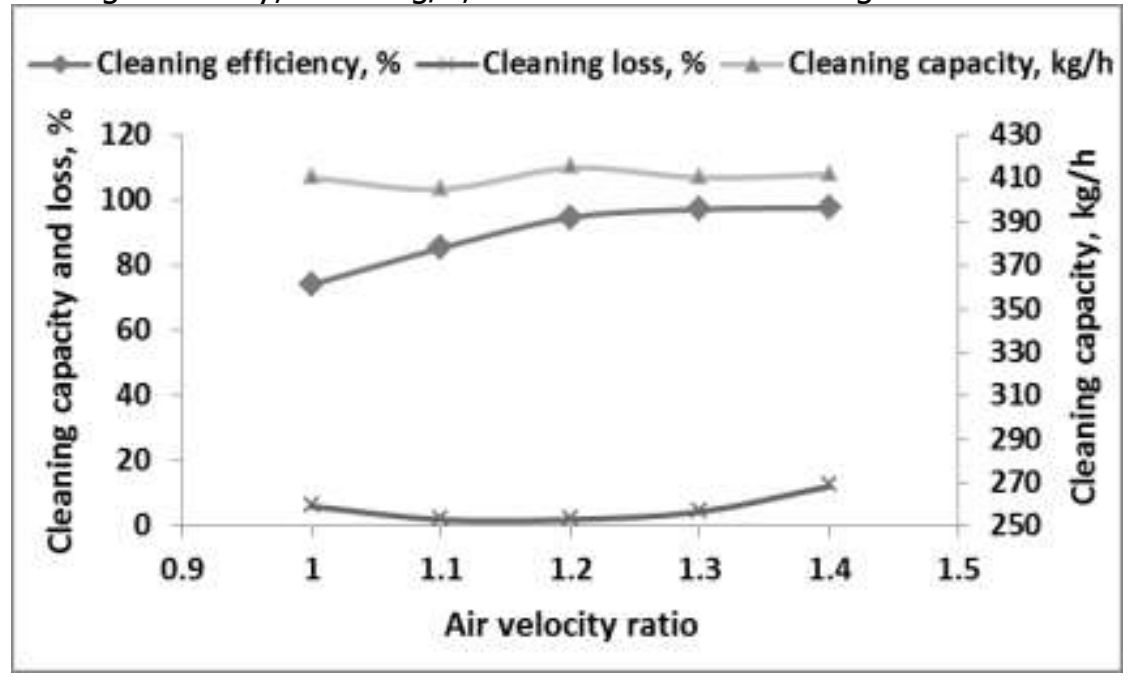

Fig. 7: Effect of air velocity ratio on cleaning efficiency, cleaning loss and cleaning capacity.

The analysis of variance (ANOVA) for the cleaning efficiency is presented in table 3. It is clear that the cleaning efficiency was highly correlated to the independent variables used. The determination factor, $R^{2}$ was found to be 0.789 . The general form of the equation used in this analysis was a function of kinematic factor $\left(\frac{\omega^{2} r}{g}\right)$, feed rate $\left(\frac{F}{\rho \sqrt{g r}}\right)$, air concentration coefficient $(\lambda)$, and air velocity ratio (a). According to Table 4, the developed model can be expressed as follows:

$$
\mathrm{C}_{\mathrm{e}}=93.122+20.39(\mathrm{a})-22.40(\lambda)-176.55\left(\frac{F}{\rho \sqrt{g r}}\right)-3.24\left(\frac{\omega^{2} r}{g}\right)
$$


From equation 8 , the air concentration coefficient, $\lambda=\frac{q_{s}}{\rho_{a} A V_{a}}$ and equation 9 , the air velocity ratio, $\alpha=\frac{V_{a}}{V_{t}}$.

$\mathrm{C}_{\mathrm{e}}=93.122+20.39\left(\frac{V_{a}}{V_{t}}\right)-22.40\left(\frac{q_{s}}{\rho_{a} A V_{a}}\right)-176.55\left(\frac{F}{\rho \sqrt{g r}}\right)-3.24\left(\frac{\omega^{2} r}{g}\right)$

Where:

$\mathrm{C}_{\mathrm{e}}=$ Cleaning efficiency, \%,

$F=$ Feed rate $=0.09,0.1,0.11,0.12$, and $0.13 \mathrm{~kg} / \mathrm{m}^{2} \mathrm{~s}$,

$\omega=$ Angular velocity $=25.5,36.1,44.29$, an $51.1 \mathrm{~s}^{-1}$,

$a=$ Air velocity ratio $=1.0,1.1,1.2,1.3$, and 1.4 ,

$\lambda=$ Air concentration coefficient $=0.15,0.20,0.25,0.30$, and 0.40 ,

$\rho=$ Seeds density $=930 \mathrm{~kg} / \mathrm{m}^{3}$,

$r=$ Crank radius $=7.5 \mathrm{~mm}$,

$g=$ Gravitational acceleration $=9.81 \mathrm{~m} / \mathrm{s}^{2}$,

$\mathrm{q}_{\mathrm{s}}=$ amount of impurities (shells), $\mathrm{kg} / \mathrm{s}$,

$\rho_{\mathrm{a}}=$ density of air $=1.2 \mathrm{~kg} / \mathrm{m}^{3}$,

$A=$ area of cross section of the duct $=0.18 \mathrm{~m}^{2}$,

$\mathrm{V}_{\mathrm{a}}=$ air velocity, $\mathrm{m} / \mathrm{s}$,

$V_{\mathrm{a}}=$ air velocity, $\mathrm{m} / \mathrm{s}$, and

$V_{\mathrm{t}}=$ maximum shells terminal velocity $=5.8 \mathrm{~m} / \mathrm{s}$.

The advantage of this model is that it can be used to generate numerous of predicted data for cleaning efficiency under the effect of many independent variables. It may be noticed from the equation the cleaning efficiency $\left(C_{e}\right)$ was positively related to air velocity ratio $\left(\frac{V_{a}}{V_{t}}\right)$. But, it was negatively related to air concentration coefficient $\left(\frac{q_{s}}{\rho_{a} A V_{a}}\right)$, feed rate $\left(\frac{F}{\rho \sqrt{g r}}\right)$, and kinematic factor $\left(\frac{\omega^{2} r}{g}\right)$. Based on the experiment results, an optimum combination of independent variables can be summarized for air velocity ratio $\left(\frac{V_{a}}{V_{t}}\right)$, air concentration coefficient $\left(\frac{q_{s}}{\rho_{a} A V_{a}}\right)$, feed rate $\left(\frac{F}{\rho \sqrt{g r}}\right)$, and kinematic factor $\left(\frac{\omega^{2} r}{g}\right)$ as $1.3,0.3,3.6 \mathrm{E}-4$ and 1.5 , respectively. As shown in Fig. 8, the relationship between the observed cleaning efficiency $(y)$ and predicted cleaning efficiency $(x)$ is given by the quadratic equation:

$y=-0.0168 x^{2}+3.926 x-127.09$, with coefficient of determination $R^{2}$ is 0.798 . 
Table 3. Analysis of variance for cleaning efficiency.

\begin{tabular}{|l|c|c|c|c|c|}
\hline \multicolumn{1}{|c|}{ S.V. } & df & SS & MS & F & Significance F \\
\hline Regression & 4 & 17609.61 & 4402.402 & 698.0213 & $3 \mathrm{E}-250$ \\
Residual & 745 & 4698.696 & 6.306974 & & \\
\hline Total & 749 & 22308.3 & & & \\
\hline
\end{tabular}

R-square $=0.789$

Table 4. Multiple regression analysis of cleaning efficiency.

\begin{tabular}{|c|c|c|c|c|c|c|}
\hline & Coefficients & $\begin{array}{c}\text { Standard } \\
\text { Error }\end{array}$ & $t$ Stat & $P$-value & $\begin{array}{c}\text { Lower } \\
95 \%\end{array}$ & $\begin{array}{c}\text { Upper } \\
95 \%\end{array}$ \\
\hline Intercept & 93.12202 & 1.117005 & 83.36761 & 0 & 90.92917 & 95.31487 \\
\hline air velocity & 20.39191 & 0.648433 & 31.448 & $8.4 \mathrm{E}-139$ & 19.11894 & 21.66488 \\
\hline air concentration & -22.4066 & 1.073907 & -20.8646 & $1.73 \mathrm{E}-76$ & -24.5148 & -20.2983 \\
\hline feed rate & -176.553 & 6.484327 & -27.2276 & $7.6 \mathrm{E}-114$ & -189.283 & -163.823 \\
\hline kinematic & -3.24588 & 0.129687 & -25.0287 & $8.2 \mathrm{E}-101$ & -3.50048 & -2.99129 \\
\hline
\end{tabular}

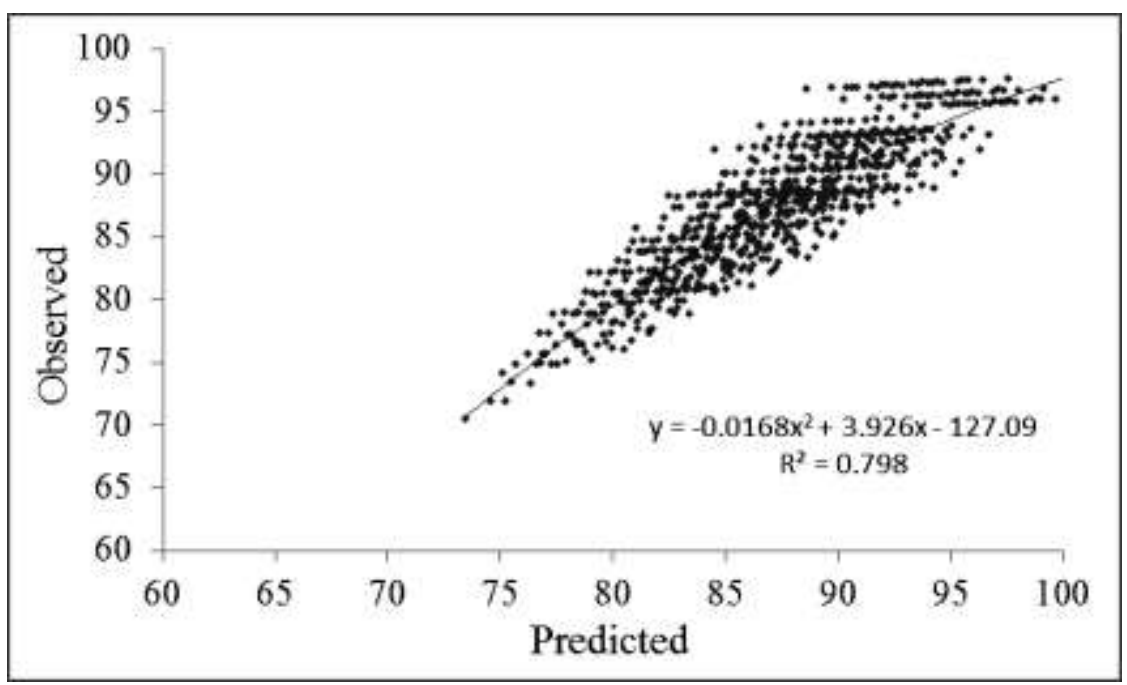

Fig. 8. The relationship between predicted cleaning efficiency and observed cleaning efficiency. 


\section{CONCLUSION}

The conclusions of the present study can be summarized as follow:

1- Experimental results show that the optimal kinematic $\left(\omega^{2} \mathrm{r} / \mathrm{g}\right)$ was 1.5 to achieve the desired performance of cleaner machine, that is, cleaning efficiency $=97.5 \%$, cleaning loss $=2.45 \%$ and cleaning capacity $=410 \mathrm{~kg} / \mathrm{h}$.

2- The load on the sieve plays a very important role in the performance on the cleaning machine. It is impossible to achieve a high degree of cleaning efficiency with a high load on the sieve. Generally, the feed rate was selected as 0.11 $\mathrm{kg} / \mathrm{m}^{2} \mathrm{~s}$ that it corresponded to the desired requirement, that is, cleaning efficiency $=97.8 \%$, cleaning losses $=3.1 \%$ and cleaning capacity $=410 \mathrm{~kg} / \mathrm{h}$.

3- The optimal performance of the experimental cleaner machine was recorded at 0.3 air concentration to achieve $97.2 \%$ cleaning efficiency, $3.8 \%$ cleaning loss, and $400 \mathrm{~kg} / \mathrm{h}$ cleaning capacity.

4- The air velocity ratio did not have a significant effect on the cleaning capacity.

5- The air stream velocity ratio was a major controlling factor that affects the cleaning efficiency and cleaning losses. The air velocity ratio which fulfilled the best result was around 1.2 to 1.3 (air velocity $=6.96 \mathrm{~m} / \mathrm{s}-7.54 \mathrm{~m} / \mathrm{s}$ ).

\section{Suggestion and recommendation:}

1- Adding a straightener at the fan delivery side to help in getting regular air distribution.

2- Machine width can be increased from 75 to $100 \mathrm{~cm}$ to increase the machine capacity.

\section{REFERENCES}

1. Abd El-Tawwab, I. M., M, A. Baiomy and S. El-Khawaga. 2007. Design and fabrication of a local rice separating machine. J. Agric. Sci. Mansoura Univ., 32(7): $5355-5368$.

2. Adewumi, B. A., O. C. Ademosun and A. S. Ogunlowo. 2006. Preliminary investigation on the distribution and spread pattern of cowpea in a cross flow grain separator. Agricultural Engineering International: the CIGR E journal. Manuscript FP 06 020. Vol III.

3. Amin, E. A., 1994. Development of grading machine for some Egyptian farm crops. J. Agric. Sci., Mansoura Univ., 19 (7): 2398 - 2411.

4. Gharibzahedi SMT, Mousavi SM, Moayedi A, Taheri Garav and A, Alizadeh SM 2010b. Moisture-dependent engineering properties of black cumin (Nigella Sativa L.) seed. Agric Eng Int: CIGR Journal. 12 (1): 194-202. 
5. Hollatz, B and G. R. Quick. 2003. Combine tailings returns, part 1: the effects of combine performance and settings on tailings. In e- Proceedings of the International Conference on Crop Harvesting and Processing. Kentucky USA. ASAE Publication Number 701P1103e. St Joseph, Mich. ASAE. 22 Pp .

6. Kanafojsski, Cz. and T. Karwowski. 1976. Agricultural machines, Theory and construction., Vol. 2: Crop harvesting Machines by the Foreign Scientific Publications Department of the National Center for Scientific, Technical and Economic Information.

7. Klenin, N. I., I. F. Popov and V. A. Sakun. 1985. Agricultural Machines (Theary of operation, Computation of Controlling Parameters and the Conditions of Operation). Amerind co., PVT, LTD, New york. PP. 633.

8. Mohsenin, N.N. 1970. The Properties of Plant and Animal Materials. New York: Gordon and Breach.

9. Murphy, G. 1950. Similitude in Engineering. New York. The Ronald Press Co.

10. Nwokolo E. and Smartt J. 1996. Peanut (Arachis hypogaea L.). In: Food and feed from legumes and Oilseeds. Chapman and Hall: $1^{\text {st }}$ edition, London, New York, 4858.

11. Picket, L. K. and N. L. West. 1988. Agricultural machinery- functional elementsthreshing, separating and cleaning. In CRC Handbook of Engineering in Agriculture. Vol 1 Eds R. H. Brown. CRC Press. Florida USA. Pp 65-85.

12. Zhao, Y., P. Wacker and H.D. Kutzbach. 1999. Investigations on winnowing steps in the combine harvester. In proceedings of International Conference on Agricultural Engineering (99-ICAE), Beijing, pp 225-231. 


\title{
تطوير وتصنيع آلة تنظيف الفول السودانى
}

\author{
إبراهيم محمد عبد التواب \\ معهُ بحوث العندسة الزراعية - مركز البحوث الزراعبة- الدقى - الجيزة.
}

يعتبر محصول الفول السودانى من المحاصيل الصيفية الرئيسية فى الأراضى الجديدة والتى غالبا

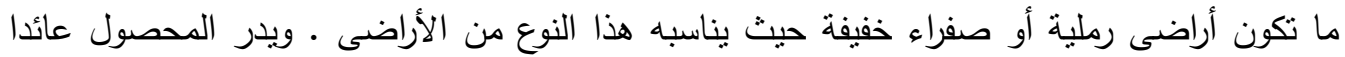
نقديا سريعا للمزارع لذا يفضل زراعته فى هذه الأراضى مع اتباع دورة زراعية ثنائية أو ثلاثية حيث

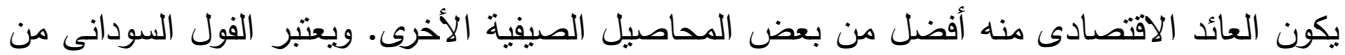
محاصيل التصدير الهامة حيث يستهلك حوالى 65-70 ٪ من الناتج محليا و يصدر منه 30-35 ٪ بهنئ للدول الأوروبية والعربية.

تم تطوير وتصنيع آلة لتنظيف بذور الفول السودانى اعتمادا على نظرينى الفصل الهوائى والميكانيكى. واشتملت مكونات الآلة على وحدة فصل هوائى للتخلص من القشر اعنمادا على السرعة الحرجة للحبوب، وحدة فصل ميكانيكى عبارة عن ثلاث غرابيل مسطحة لفصل القرون عن الحبوب المقشرة وكذلك التخلص من الحبوب والقرون الضامرة. تم اختبار اداء الآلة عند معامل الحركة للغربال

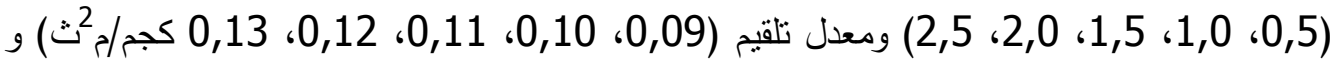

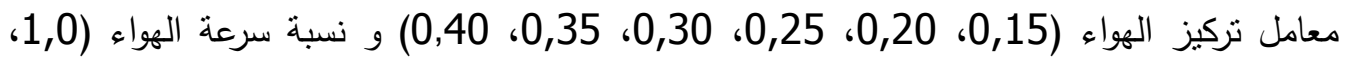
1,1 1,2، 1,3، 1,4) وتم حساب كفاءة التنظيف و فاقد التنظيف وكذلك الانتاجية. لذلك كان الهدف من هذا البحث هو: 1- دراسة بعض الخواص الطبيعية والايروديناميكية لبذور الفول السودانى. 2- نطوير آلة تتظيف محلية الصنع لتلائم محصول الفول السودانى. 3- دراسة اهم العوامل الهندسية والتصميمية على آلة التنظيف المطورة.

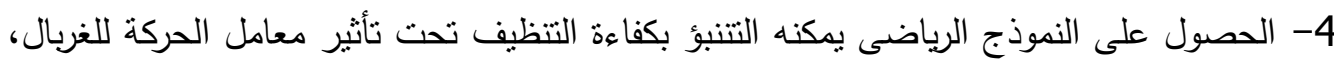
معدل التلقيم، معامل نركيز الهواء، ونسبة سرعة الهواء.

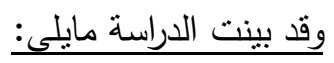
1- أعلى كفاءة تتظيف للآلة (97,5 \%) عند معامل الحركة للغربال (1,5)، معدل التلقيم (0,11)

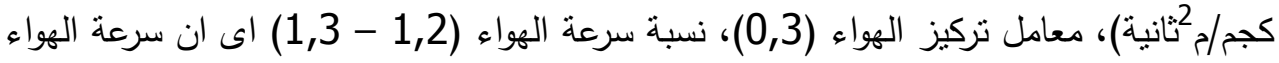
تتراوح (7,56 - 6,54) منر /ثانية. 2- بلغت الإنتاجية الكلية عند معاملات التتغيل الموصى بها حوالى 410 كجم/ساعة. 3- أثتتت التجارب ان نسبة الفاقد لبذور الفول السودانى بلغت 2,45 ٪ عند معاملات التشغيل 